\title{
A Study Showing the Relationship Between Extent of Participation of Rural Youths Towards Management Activities Relating to Farming with Socio - Economic and Psychological Characteristics in Jorhat District of Assam, India
}

\author{
M. Buragohain ${ }^{1 *}$, N. Bordoloi ${ }^{1}$ and I. Lego ${ }^{2}$ \\ ${ }^{1}$ Department of Extension Education, Assam Agricultural University, Jorhat-13, Assam, India \\ ${ }^{2}$ Department of Extension Education, College of Post Graduate Studies, CAU, \\ Meghalaya, India \\ *Corresponding author
}

\section{Keywords}

Rural youth,

Participation,

Management

activities

\section{Article Info}

Accepted:

20 December 2017

Available Online:

10 January 2018

\section{A B S T R A C T}

The study entitled "A study showing the relationship between extent of participation in management activities, with socio-economic and psychological characteristics of rural youths towards farming in Jorhat district of Assam", following Ex-Post-Facto research design. A total of 200 respondents were selected by using multistage purposive cum random sampling technique. The data were collected by means of personal interview schedule during $25^{\text {th }}$ Feb, $2016-3^{\text {rd }}$ April, 2016. The findings revealed that age (0.589), size of operational land holding (0.172), annual income of the family (0.092), training exposure $(0.483)$ and mass media exposure $(0.435)$ of the respondents is positively significant and highly correlated with extent of participation in management activities. However, occupation of parents $\left(\chi^{2}=30.254^{*}\right)$ had significant association at 5 per cent probability level with extent of participation in management activities. The regression coefficient of age, age $(b=0.534)$, sources of farm machineries and farm implements $(b=$ $-0.343)$ and attitude towards farming $(\mathrm{b}=1.074)$ were found to be significant. The coefficient of multiple determinations $\left(\mathrm{R}^{2}=0.624\right)$ explain together 62.40 per cent to the total variation on the extent of participation in management activities.

\section{Introduction}

The World Bank (2001) noted that majority of the world population consists of young people, three quarters of them living in the rural areas. Adesope (1999) in Matthews-Njoku and Ajaero (2007) noted that youths represent the most active segment of the population and the engine that would do most productive work of the society. Youths constitute a formidable force in the agricultural production process, constituting a sizeable proportion of the workforce especially in the rural areas. Adebayo et al., (2006) noted that despite their (youths) rich rural life, farming background and experience, rural youths are yet to actively and productively participate in the development of the nation's agricultural sector. This is related to the dearth of viable institutional framework for mobilizing, developing and channelling the unique 
abilities, experiences and aspirations of rural youths towards agriculture.

State like Assam where rice is the main basis of agricultural system and farmers of Assam are characterized by small land holding, less cash inflow and poverty. The development of this region depends on the development of agriculture through modern technologies and more participation of rural youths. Further, the participation of rural youths in rice cultivation will be motivating factor for developing a sense of work culture for the youths of the non sampled area and also for generating income through such production oriented activities. Extent of participation in management activities was defined as the frequency at which the rural youth took active part in various farm management activities. In this study active participation of the rural youths in management activities related to various aspects of farming were identified where participation of rural youths is possible. The focus of the study was to examine the relationship between participation of the rural youths in management activities with various socio-economic and psychological characteristics towards farming in Jorhat district of Assam.

\section{Materials and Methods}

The population of the study comprised the rural youths in the study area that were engaged in farm operation during the study. Jorhat district was purposively selected for the present study.Two sub-division viz. Jorhat and Titabor were selected randomly from Jorhat district. Two A.D.O. circles from each sub division were selected randomly. These were Dhekorgorah and Teok A.D.O. circles under Jorhat sub-division and Madhapur and Baghchung A.D.O. circles under Titabar subdivision were selected randomly. Two villages from each A.D.O. circle were selected randomly for the present study. Thus altogether there were eight randomly selected villages. Hence a total of 200 rural youths were sampled.

Data were collected using structured schedule and open ended questions administered to 200 randomly selected respondents. Variable for analysis included the following: Age, Education, Type of family, Size of family, Operational land holdings, Annual income of family, Occupation of parents, Training exposure, Attitude towards farming, Mass media exposure and level of participation in farm operations, management activities and decision making. Data analysis was carried out through the use of frequency counts, percentages.

\section{Results and Discussion}

The independent variable age $(r=0.589)$, size of operational land holdings $(r=0.172)$, annual income of the family $(\mathrm{r}=0.092)$, training exposure $(\mathrm{r}=0.483)$ and mass media exposure $(\mathrm{r}=0.435)$ of the respondents is positively significant and highly correlated with extent of participation in management activities at 1 per cent level of probability.

It was also found that size of family $(r=0.143)$ and attitude towards farming $(\mathrm{r}=0.637)$ is positively significant and moderately correlated at $0.05 \%$ probability level. It was further seen from the analysis that there is a negative and non-significant relationship between sources of farm machineries and farm implements $(r=$ 0.019) with extent of participation in management activities (Table 1).

The Table 2 showed that occupation of parents $\left(\chi^{2}=30.254\right)$ had significant association at 5 per cent probability level with extent of participation in management activities educational level $\left(\chi^{2}=28.768\right)$ and type of family $\left(\chi^{2}=2.420\right)$ showed no association with extent of participation in management 
activities. It was evident that out of the eleven (11) variables, the regression coefficient of age $(b=0.538)$, sources of farm machineries and farm implements $(b=-0.343)$ and attitude towards farming $(b=1.074)$ were found to be significant. These (3) three variables could, therefore, be termed as good predictors of rural youth's extent of participation in management activities.

Table.1 Co-efficient of correlation between extent of participation in management activities and independent variables

\begin{tabular}{|c|c|c|c|}
\hline Sl. No. & Variable & r value & t value \\
\hline 1 & Age & $0.589^{* *}$ & 4.299 \\
\hline 2 & Size of family & $0.143^{*}$ & 2.302 \\
\hline 3 & Size of operational land holding (in ha) & $0.172^{* *}$ & 4.928 \\
\hline 4 & Annual income of the family & $0.092 * *$ & 8.135 \\
\hline 5 & Sources of farm machineries and farm implements & $-0.019^{\mathrm{NS}}$ & 0.09 \\
\hline 6 & Training exposure & $0.483^{* *}$ & 5.304 \\
\hline 7 & Attitude towards farming & $0.637^{*}$ & 2.236 \\
\hline 8 & Mass media exposure & $0.435 * *$ & 7.700 \\
\hline $\begin{array}{l}* \text { denotes } \\
\text { denotes s } \\
\text { vS }=\text { Non-s } \\
\text { l.f. }=\text { n-2= } \\
r=\text { Co-effic } \\
=\text { Calculat }\end{array}$ & $\begin{array}{l}\text { ignificant at } 0.01 \text { level of probability } \\
\text { gnificant at } 0.05 \text { level of probability } \\
\text { gnificant } \\
00-2=198 \text { for all case } \\
\text { ent of correlation } \\
\text { d t value }\end{array}$ & & \\
\hline
\end{tabular}

Table.2 Association of selected socio-personal characteristics of the respondents with participation in management activities

\begin{tabular}{|c|l|c|}
\hline Sl. No. & \multicolumn{1}{|c|}{ Independent variable } & Chi test \\
\hline $\mathbf{1}$ & Education level & $28.768^{\mathrm{NS}}$ \\
\hline $\mathbf{2}$ & Type of Family & $2.420^{\mathrm{NS}}$ \\
\hline $\mathbf{3}$ & Occupation of parents & $30.254^{*}$ \\
\hline $\begin{array}{l}\text { * denotes significant at } 0.05 \text { level of probability } \\
\text { NS= Non-significant } \\
\text { d.f }=\mathrm{n}-2=200-2=198\end{array}$ \\
\hline
\end{tabular}


Table.3 Multiple regression analysis of extent of participation in management activities with independent variables

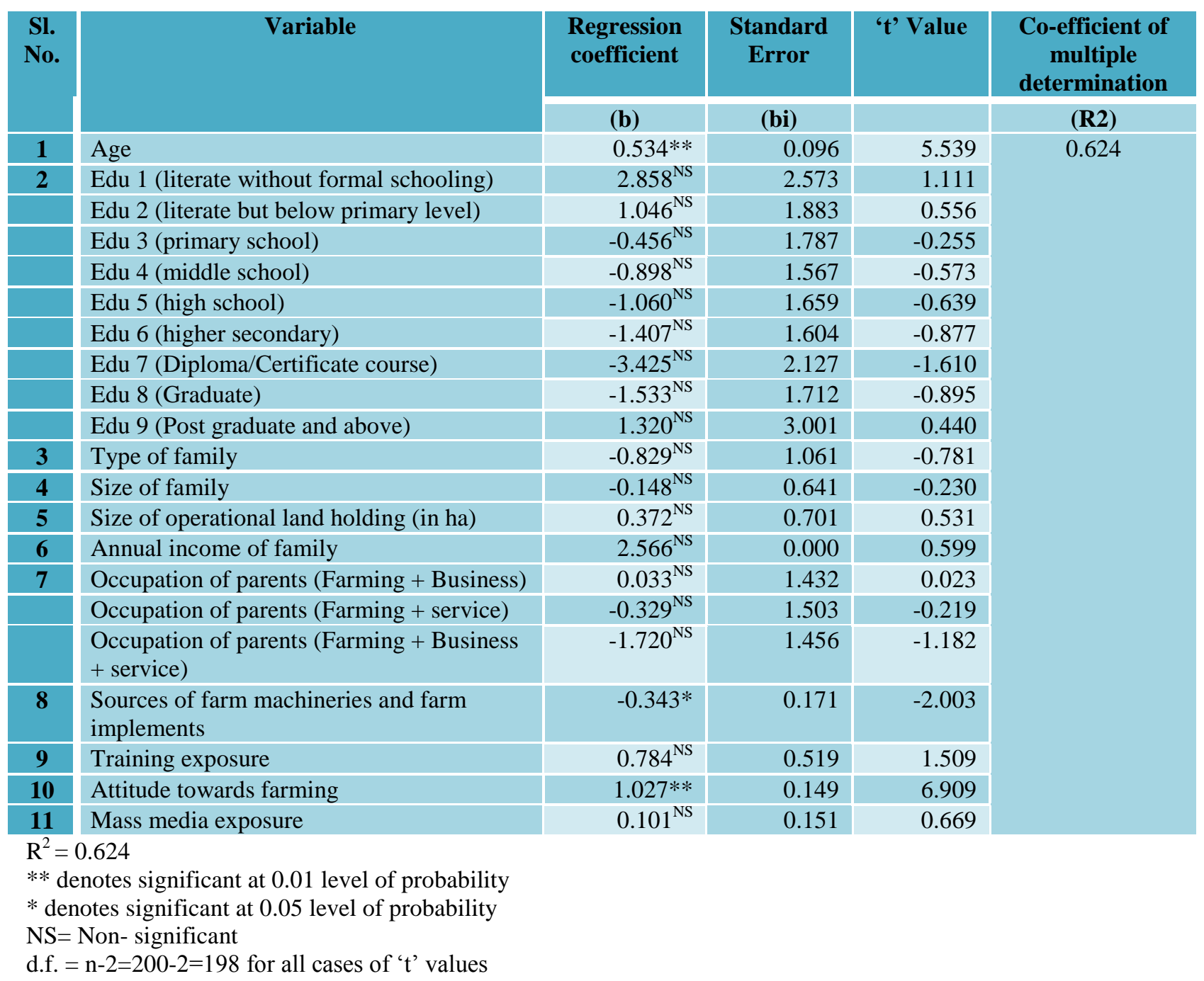

The co-efficient of multiple determinations $\left(\mathrm{R}^{2}\right)$ with eleven independent variables was found to be 0.624 . It indicates that the set of eleven variables could explain together 62.40 per cent to the total variation on the extent of participation in management activities (Table $3)$.

The relationship of selected characteristics of rural youth with participation in management activities in rural areas of Jorhat district revealed that age, size of operational land holding, annual income of the family, training exposure and mass media exposure of the respondents is positively significant and highly correlated with extent of participation in management activities. However, occupation of parents had significant association at 5 per cent probability level with extent of participation in management the regression coefficient of age, sources of farm machineries and farm implements and attitude towards farming were found to be significant. The co-efficient of multiple determinations $\left(R^{2}=0.624\right)$ explain together 62.40 per cent to the total variation on the extent of participation in management activities. Therefore, Government and extension 
personnel should target and encourage the rural youths to play more active role in agricultural management activities so as to achieve a broad-based agricultural development focusing on the technological and socio-economic needs of all categories of farmers, especially the youths.

\section{References}

Adebayo, K., Awotunde, M., Okuneye, P.A. and Okonowo, U.V. 2006. Assessment of secondary school agricultural education programme in the rural areas of Imo State, Nigerian journal of rural sociology, Vo1.6. Nos. 1 and 2, October, pp. $13-22$.
Adescope, O. M. 1999. Evaluation of youth participation in community development projects in river state, Nigeria Unpublished M.Sc. Thesis, Department of Agricultural Economics and Extension, Federal university of technology, Owerri.

Matthews - Njoku, E.C. and Ajaero, J.O. 2007. Role of youths in food security in Ikeduru local government area of Imo State, Nigeria. Global approaches to extension practice, 3, (1), and pp.36 41.

World Bank 2001. The world youth forum report, Washington, D.C.

\section{How to cite this article:}

Buragohain, M., N. Bordoloi and Lego, I. 2018. A Study Showing the Relationship Between Extent of Participation of Rural Youths Towards Management Activities Relating to Farming with Socio - Economic and Psychological Characteristics in Jorhat District of Assam, India. Int.J.Curr.Microbiol.App.Sci. 7(01): 2882-2886. doi: https://doi.org/10.20546/ijcmas.2018.701.343 